\title{
Optimization and Kinetics of Zirconium Oxychloride (ZOC) Dissolution Using $\mathrm{HNO}_{3}$
}

\author{
Maria Veronika Purwani and Muzakky* \\ Center for Accelerator Science and Technology - National Nuclear Energy Agency, \\ Jl. Babarsari No. 21, POB 6101 ykbb, Yogyakarta 55281, Indonesia
}

\section{${ }^{*}$ Corresponding author: \\ tel: $+62-81328658366$ \\ email:muzakkyi@batan.go.id}

Received: August 27, 2018

Accepted: March 14, 2019

DOI: $10.22146 /$ ijc.38288

\begin{abstract}
The design of chemical reactors cannot be separated from the optimization data and reaction kinetics obtained from experimental measurements. Through the design idea, the purpose of this study was to obtain optimization data and the kinetics of Zirconium Oxide Chloride (ZOC) dissolution reactions using $\mathrm{HNO}_{3}$. The dissolution optimization was carried out by dissolving $\mathrm{ZOC}$ solids using $\mathrm{HNO}_{3}$ in a stirred container with several variations as contact time, $\mathrm{HNO}_{3}$ concentration, stirring and temperature. With the initial concentration of ZOC $6 \mathrm{~g}$ and $\mathrm{HNO}_{3} 6 \mathrm{M}$ obtained the best optimum contact time of 2 min and the number of conversions ( $\alpha$ ) of 0.96. Evaluation of kinetic data has been done based on the three types of shrinking core models. The results of kinetic predicted that the control of the $\mathrm{ZOC}$ dissolution reaction in $\mathrm{HNO}_{3}$ was in accordance with the surface chemical reaction model. Optimization results were showed that the best of contact time at $2 \mathrm{~min}, 6 \mathrm{M} \mathrm{HNO}_{3}$ concentration, temperature $60^{\circ} \mathrm{C}$ and stirring speed $75 \mathrm{rpm}$. The correlation between temperature $(T)$ and the calculated reaction rate constant $(k)$ corresponds to equation $\ln k_{r}=-2297.6 / T+6.2172$, with frequency factors $A=501.29$ and activation energy $E=19.09 \mathrm{~kJ} / \mathrm{mole}$.
\end{abstract}

Keywords: ZOC; mini pilot plant; optimization; kinetics; Arrhenius formula

\section{- INTRODUCTION}

The Center for Science and Accelerator Technology (CSAT) - National Nuclear Energy Agency - Yogyakarta, through the DIPA and InSinas Ristek program has succeeded in making several superior materials based on zircon minerals. One of the superior products as Zirconium oxychloride $\left(\mathrm{ZrOCl}_{2}\right)$ which is often abbreviated as $\mathrm{ZOC}$ [1]. Unfortunately, the ZOC cannot be mentioned as nuclear material, because the requirement of the hafnium (HF) content of less than $50 \mathrm{ppm}$ has not been fulfilled [2]. The production of ZOC compounds was begun with the digestion of zircon sand $\left(\mathrm{ZrSiO}_{4}\right)$ with sodium hydroxide $(\mathrm{NaOH})$ at $650-750{ }^{\circ} \mathrm{C}$. Then, after being leached by water [3] and chloride acid, ZOC was formed [4]. To obtain the super-pure nuclear materials, it should be done such the purification process of Hf [1].

After going through several separation studies, in 2016 CSAT decided on the method of separating Zr and Hf by extracting solvent using a mixer-settler [5]. The selection of extract solvent used was tributyl phosphate
(TBP), taking into account the distribution efficiency (KD) $\mathrm{Zr}$ into the organic phase which is quite high [5]. Solvent extraction of TBP has been carried out by previous researchers since 1955 by Cox et al. [6]. But in the past few years, it turned out that TBP was also still used by Pandey et al. [7], Banda et al. [8] and Aliakbari et al. [9], with various modifications. However, research on the optimization and kinetics of $\mathrm{Zr}$ (Hf) nitrate as a feed, from the results of ZOC dissolution is still rare. Biswas's study of kinetics [10] could not be used as a reference because the feed system was carried out in a chloride acid system. Mean each of Murali et al. [11] and Barba et al. [12], used ZOC different materials from this research.

Based on Pandey et al. [7] and Murali et al. [11], the success of $\mathrm{Zr}$ purification from HF with solvent extraction was determined by the acidity of the feed in its liquid phase. Pandey et al. [13] have investigated that the TBP extractant was the best for separating $\mathrm{Zr}$ from HF, with the nitric acid system. This matter is due to the 
mass transfer of $\mathrm{Zr}^{4+}$ into the organic phase will be influenced by the presence of several species such as $\mathrm{ZrOH}^{3+}$ and $\mathrm{Zr}_{3}(\mathrm{OH})_{8}{ }^{+4}$ in the nitric acid condition [13]. Through the idea of making a ZOC dissolution reactor design, then the purpose of this study to optimize and kinetics of ZOC dissolution with $\mathrm{HNO}_{3}$ would be materialized. The optimization will be carried out as a function of contact time, nitric acid concentration, temperature and stirring speed while the kinetics of the Shrinking Core Model was chosen because it matches with the ZOC dissolution system in nitric acid which was classified as Fluid-Particle Reactions [14]. The optimization and kinetics dissolution of ZOC data were expected to be used to make ZOC dissolution reactor design [14], before entering into the extraction process using a mixer settler [5].

\section{- EXPERIMENTAL SECTION}

\section{Materials}

The materials used as feed were $\mathrm{ZrOCl}_{2} \cdot \mathrm{xH}_{2} \mathrm{O}$ (ZOC) as the digestion processed product of zircon sand $\left(\mathrm{ZrSiO}_{4}\right)$, at the process technology division of PSTABATAN Yogyakarta. $\mathrm{HNO}_{3}$, made by Merck E, and labmade distilled water of PSTA laboratory.

\section{Instrumentation}

A set of X-ray fluorescent spectrometer device (XRF) equipped with $\mathrm{SiLi}$ detector, ${ }^{241} \mathrm{Am}$ radioactive source. The XRF device was connected to a personal computer with the Maestro software data processor.

\section{Procedure}

Amount of $6 \mathrm{~g}$ of ZOC 100 mesh was put into a $250 \mathrm{~mL}$ beaker glass equipped with a cooling and magnetic stirrer motor and a magnetic stirrer (Fig. 1). Furthermore, $100 \mathrm{~mL}$ of $\mathrm{HNO}_{3} 3 \mathrm{M}$ was added, then it was stirred at a fixed rate of $75 \mathrm{rpm}$ at room temperature. The ZOC dissolution process was first carried out in $1.0 \mathrm{~min}$ and then carried out at intervals of 0.5 to $5 \mathrm{~min}$. At each interval of $0.5 \mathrm{~min}, 2.5 \mathrm{~mL}$ samples were taken for analyzing the analysis product by using XRF. The second variation (2) was done by repeating the above work by concentration $\mathrm{HNO}_{3}$ from 3 to 7 molar. Then the third variation (3) was conducted in the same way but at a

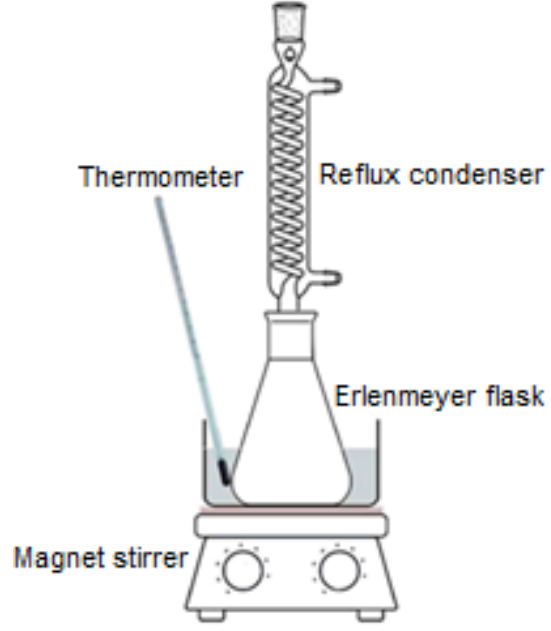

Fig1. Experimental investigation device scheme

temperature from 40 to $70{ }^{\circ} \mathrm{C}$, while fourth variation (4) was conducted at stirring speed 50 to $150 \mathrm{rpm}$. The result of the dissolution process of each sample taken was analyzed by XRF device using ${ }^{241} \mathrm{Am}$ excitation with $\mathrm{SiLi}$ detector for $1000 \mathrm{sec}$.

\section{- RESULTS AND DISCUSSION}

\section{Optimization}

\section{Effect of contact time}

Nitric acid is a strong acid that can be easily deprotonated. Hence hydrogen can be transferred to metal complexes, and according to Pandey et al. [13], the dissolution chemical reaction between $\mathrm{ZOC}$ and $\mathrm{HNO}_{3}$ could produce $\mathrm{ZrO}\left(\mathrm{NO}_{3}\right)_{2}$,

$$
\begin{aligned}
& \mathrm{ZrOCl}_{2} \cdot \mathrm{xH}_{2} \mathrm{O}(\mathrm{s})+2 \mathrm{HNO}_{3}(\mathrm{I}) \rightarrow \mathrm{ZrO}\left(\mathrm{NO}_{3}\right)_{2}(\mathrm{I}) \\
& +2 \mathrm{HCl}(\mathrm{I})+\mathrm{xH}_{2} \mathrm{O}(\mathrm{I})
\end{aligned}
$$

According to Gharabaghi et al. [15], the contact time is the time required for a reactant (solid) with the aid of the reactant to be transformed into a complete product fraction (liquid) spontaneously and resulting in a maximum conversion. The product conversion can be expressed as the solid conversion fraction ( $\alpha$ ),

$\alpha=\frac{\text { weight of } Z \text { r in solution }(\mathrm{g})}{\text { weight of } Z \text { r in feed }(\text { solid })(\mathrm{g})}$

The results in Fig. 2 show the correlation between dissolution time and conversion (a) $\mathrm{Zr}$ at feed conditions $6 \mathrm{~g}$ of ZOC reacted with $100 \mathrm{~mL} \mathrm{HNO}_{3} 4 \mathrm{M}$, $75 \mathrm{rpm}$ stirring rate, dissolution temperature $28^{\circ} \mathrm{C}$, and reaction time from 0.5 to $5.0 \mathrm{~min}$. It is shown that the 
optimum reaction time was after $2 \mathrm{~min}$ with a conversion value of 0.8. It means that the formation of $\mathrm{ZrO}\left(\mathrm{NO}_{3}\right)_{2}$ in $4 \mathrm{M} \mathrm{HNO}_{3}$ solvent reached $80 \%$ for $2 \mathrm{~min}$, while the $20 \%$ rest was insoluble. Based on Safari et al. [16] the longer the contact time will affect the mass displacement of the solid particles into the acid solvent. The optimization results of 2 min contact time turned out to be in accordance with Pandey's et al. [13].

\section{Effect of $\mathrm{HNO}_{3}$ concentration}

The effect of $\mathrm{HNO}_{3}$ concentration on the ZOC dissolution rate was investigated under fixed experimental conditions temperature of $313 \mathrm{~K}$, the weight of ZOC solid of $6 \mathrm{~g}, 100 \mathrm{~mL}$ of $\mathrm{HNO}_{3}$, a stirring speed of $100 \mathrm{rpm}$ and dissolution time of 0.5-2.0 min. As observed in Fig. 3, the $\mathrm{Zr}$ dissolution fraction increases significantly as a function of initial $\mathrm{HNO}_{3}$ concentration. The results in Fig. 3 shows that $6 \mathrm{M}$ of $\mathrm{HNO}_{3}$ concentration the $\mathrm{Zr}$ dissolution fraction was observed at 1 to $2 \mathrm{~min}$. The result of ZOC was almost completely dissolved. Conversely, decreasing the initial $\mathrm{HNO}_{3}$ concentration to $3 \mathrm{M}$ resulted in a $\mathrm{Zr}$ dissolution fraction of only 0.8308 when subjected to the same conditions.

Based on Pandey et al. [13], in a solution of $\mathrm{HNO}_{3}$ zirconium ions will form some speciation equilibrium such as $\mathrm{Zr}^{4+}, \mathrm{ZrOH}^{3+}$, and $\mathrm{Zr}_{3}(\mathrm{OH})_{4}{ }^{8+}$. Each of these zirconium ion species has different equilibrium strength in the $\mathrm{HNO}_{3}$ atmosphere. Consequently, the presence of ionic species will affect the mass transfer of the water phase into the organic phase. This is particularly the case

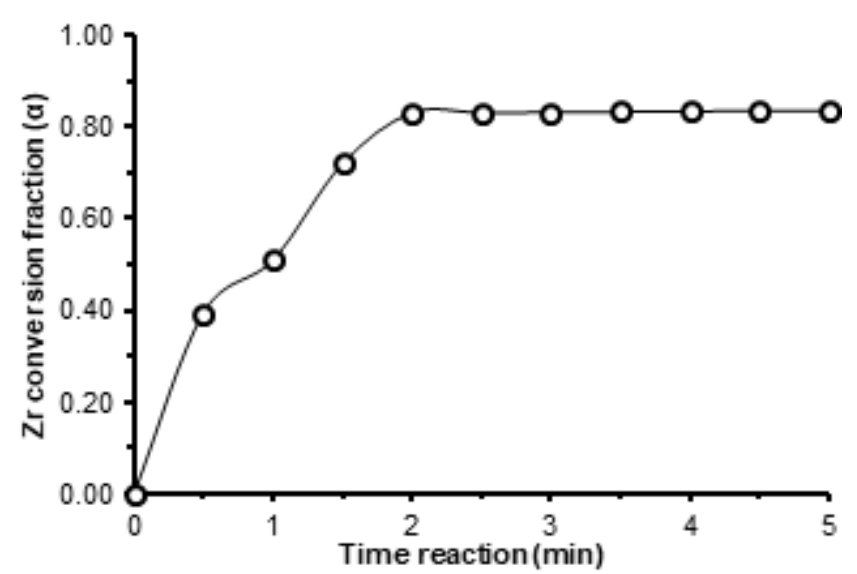

Fig 2. Correlation between the conversion ( $\alpha$ ) with the contact time ( $\mathrm{min}$ ) for the separation of $\mathrm{Zr}$ and Hf by Tri Butyl Phosphate (TBP) extractant. At $6 \mathrm{M} \mathrm{HNO}_{3}$, the effect of $\mathrm{ZrOH}^{3+}$ and $\mathrm{Zr}_{3}(\mathrm{OH})_{4}{ }^{8+}$ ion species were very small. Consequently, the rest of the feed solution will exist as $\mathrm{Zr}^{4+}$ species so that the displacement into the TBP will be easier [13]. Based on Pandey et al. investigation [13], the selection of $6 \mathrm{M} \mathrm{HNO}_{3}$ has been appropriate because the higher the concentration of $\mathrm{HNO}_{3}$, the stronger the oxidation ability is.

\section{Effect of temperature}

Based on Pandey's research [13], the initial extraction rate or conversion would increase with an increase in temperature. The temperature will contribute to both the intrinsic kinetics and mass transfer. Variation in temperature can provide vital information regarding the controlling mechanism between them. Our study, all other operational parameters were kept constant at the ZOC weight of $6.0 \mathrm{~g}$, initial $\mathrm{HNO}_{3}$ molarity of $6 \mathrm{M}$, and a stirring speed was set to $75 \mathrm{rpm}$. The results in Fig. 4 show that the effect of reaction temperature was investigated at the range of $301-333 \mathrm{~K}$. It seems that our experiment shows that conversion will increase as a function of temperature. This turns out to be in accordance with the experiment conducted by Pandey et al. [13] that the variation of temperature will tend to increase in the temperature range of 301-333 K.

\section{Effect of stirring speed}

This experiment ZOC dissolution was expressed as $\mathrm{Zr}$ conversion fraction $(\alpha)$ as a function of stirring speed

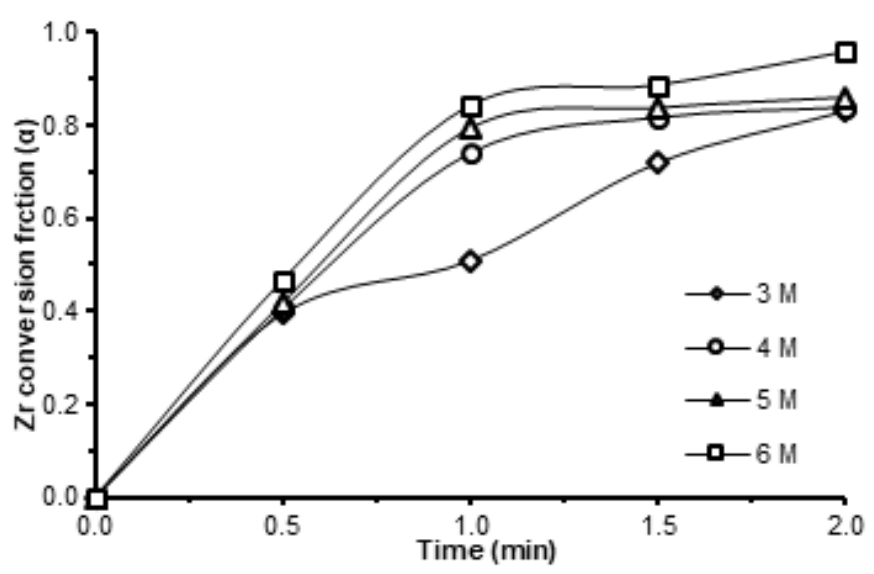

Fig 3. Correlation between time, $\mathrm{HNO}_{3}$ molarity and $\mathrm{Zr}$ conversion $(\alpha)$ 


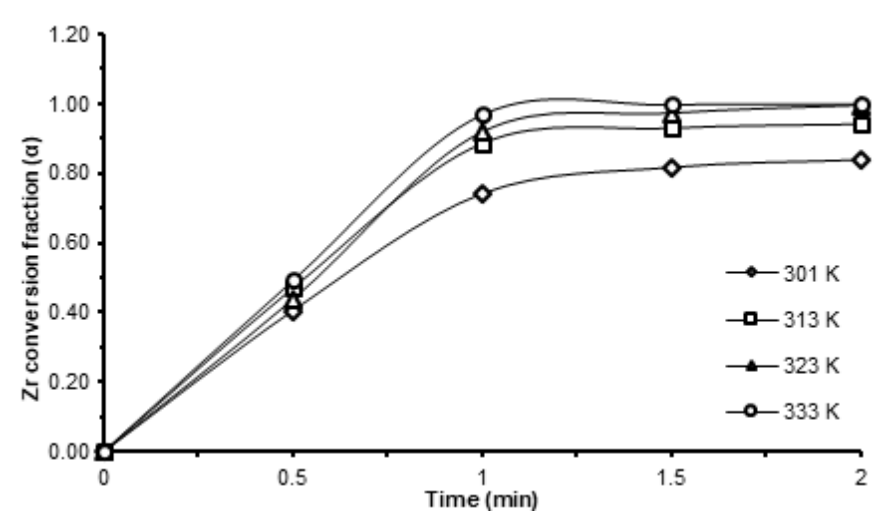

Fig 4. Correlation between time, temperature and $\mathrm{Zr}$ conversion $(\alpha)$

of 50 to $150 \mathrm{rpm}$. The concentration of nitric acid was used in the atmosphere of $6 \mathrm{M}$ and the reaction temperature of $313 \mathrm{~K}$ with a contact time of $2 \mathrm{~min}$. The results in Fig. 5 shows that the zirconium conversion fraction will increase with an increase of stirring speed from 50 to $125 \mathrm{rpm}$. Based on Pandey research [17] at a low stirring speed, the interface thickness of the film on ZOC solids is still too large so that it is difficult to penetrate by diffusion of nitric acid. As a result, the conversion of the dissolution fraction is still low, whereas at high speeds the chemical reaction will be dominant so that the fraction conversion is not affected by the stirring speed. Based on this observation, it can be concluded that both the mass transfer rate (diffusion process) and chemical reactions can affect the dissolution of the zirconium fraction into nitric acid.

\section{Kinetics Study}

Reaction kinetics data for making a reactor design has long been needed by a chemical engineer [14]. However, information about the dissolution kinetics of ZOC in $\mathrm{HNO}_{3}$ is very rarely reported. Therefore, reporting on the kinetics of the dissolution reaction is very important. This will contribute to the performance of the separation of zirconium from Hafnium in the future. The mechanism for dissolution reaction of $\mathrm{ZOC}$ in $\mathrm{HNO}_{3}$ can be classified as the dissolution of mineral particles by a solid-fluid reaction represented by the following reaction [14]:

a A fluid + b B solid $\rightarrow$ product

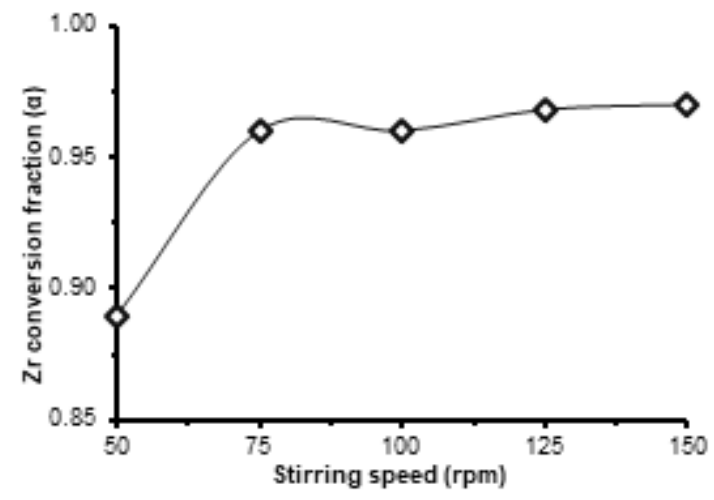

Fig 5. Correlation between stirring speed and $\mathrm{Zr}$ conversion fraction

The notation of $\mathrm{a}$ and $\mathrm{b}$ are stoichiometric coefficients, and A and B each represent dissolved fluid and solids reactants, respectively. The kinetic mechanism of the dissolution reaction is often described by a shrinking core model. According to this model, the mechanism for dissolving $\mathrm{ZOC}$ in $\mathrm{HNO}_{3}$ is assumed to be a solid-liquid phase [18]. Thus, this process will be controlled by several steps, such as diffusion through the liquid film, a surface chemical reaction, or diffusion through the product layer. The three types of shrinking core models in the dissolution process can be summarized in the following equation:

Diffusion through liquid film layer $: \mathrm{k}_{1} \cdot \mathrm{t}=\alpha$

Surface chemical reaction $: k_{r} \cdot t=1-(1-\alpha)^{1 / 3}$

Diffusion through the product layer $: \mathrm{k}_{\mathrm{d}} \cdot \mathrm{t}=1-(2 / 3) \alpha-(1-\alpha)^{2 / 3}$

Notation $\alpha$ is conversion, $k_{1}$ is a pseudo rate constant for diffusion through the fluid film, $\mathrm{k}_{\mathrm{r}}$ is a pseudo rate constant for surface chemical reactions, and $k_{d}$ is a pseudo rate constant for diffusion through the product layer, while $t$ is a time reaction. The pseudo rate constants of $k, k_{r}$ and $k_{d}$ can be obtained by results of plot $t$ versus $f$ (model), while the molarity effect of $\mathrm{HNO}_{3}$ on all three models can be shown in Fig. 6 .

Based on the shrinking core models equation (2-4) with the various molarity of $\mathrm{HNO}_{3}$, results plot of reaction times versus $f$ ( 3 models) are shown in Fig. 7(ac) and Table 1. Table 1 showed that the diffusion through the liquid film model has a wide range of $\mathrm{R}^{2}$ which is 0.8278 to 0.9434 . While the surface chemical 

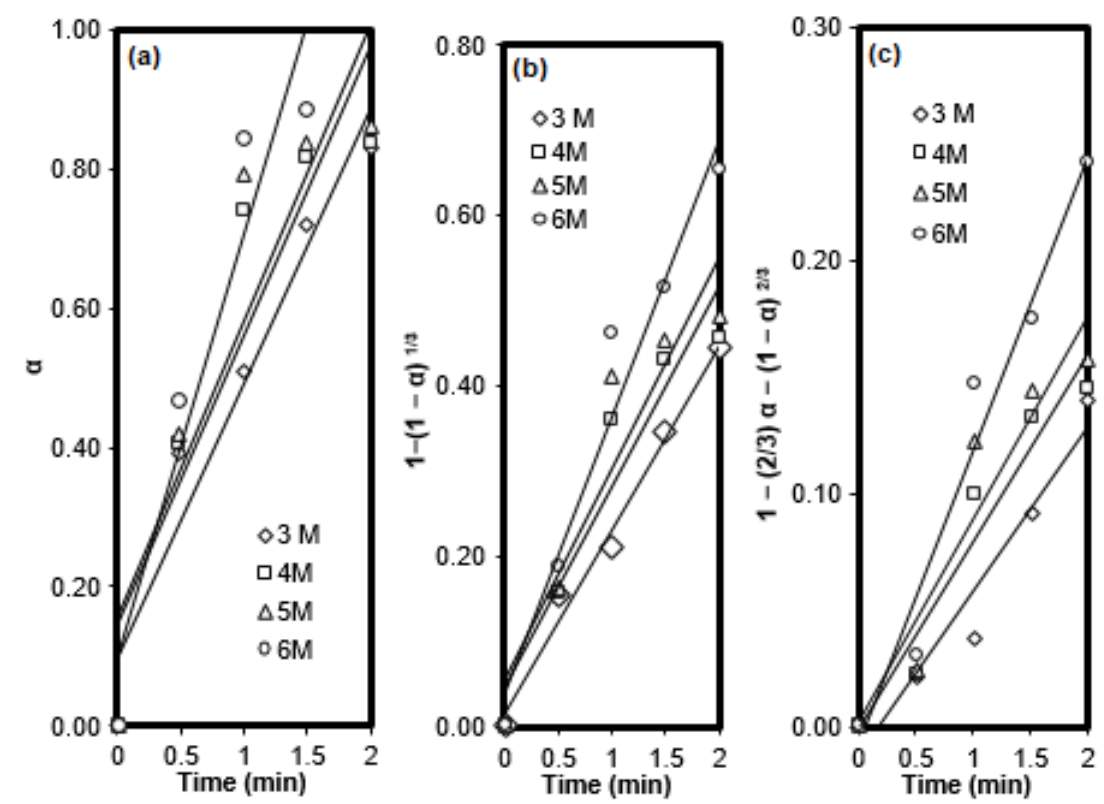

Fig 6. The plot of (a) time versus $\alpha$, (b) time versus $\left(1-(1-\alpha)^{1 / 3}\right)$, and (c) time versus $\left(1-(2 / 3) \alpha-(1-\alpha)^{2 / 3}\right)$, as a function of molarity of $\mathrm{HNO}_{3}$ respectively

reaction model has a middle range of $R^{2} 0.8861$ to 0.9865 , the diffusion through model the product layer has a narrow range of $R^{2} 0.9034$ to 0.963 . Based on Levenspiel [14], the narrowest of $\mathrm{R}^{2}$ range value indicated that diffusion through the product layer model was a controller reaction of dissolution $\mathrm{ZOC}$ in $\mathrm{HNO}_{3}$. The main role of control diffusion through the product layer model for $\mathrm{ZOC}$ in $\mathrm{HNO}_{3}$ was turned out to be in accordance with Ayanda's paper [19].

Furthermore, Fig. 7(a-c) and Table 2, have been shown the results of the application of the three types of shrinking core models (2), (3) and (4) for temperature variations. The results show that the diffusion through the liquid film model has an $\mathrm{R}^{2}$ range from 0.8003 to 0.8492 .
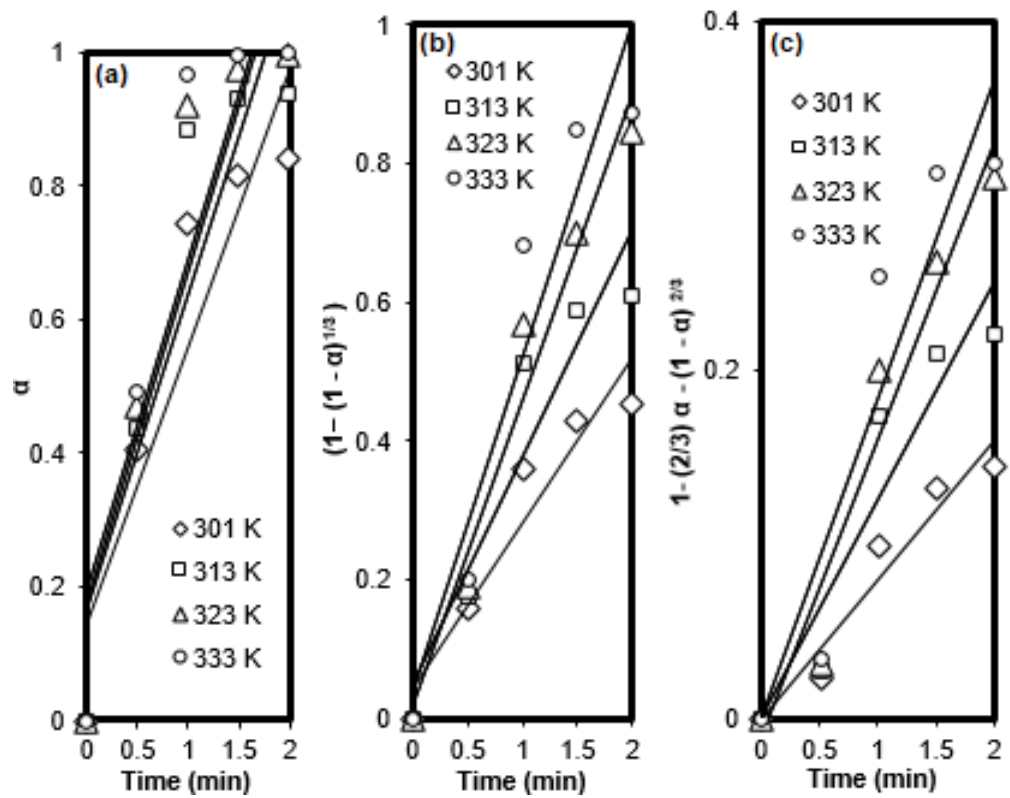

Fig 7. The plot of (a) time versus $\alpha$, (b) time versus $\left(1-(1-\alpha)^{1 / 3}\right)$, and (c) time versus $1-(2 / 3) \alpha-(1-\alpha)^{2 / 3}$, as a function of temperature respectively 
Table 1. The correlation coefficient values $\left(\mathrm{R}^{2}\right)$ of three kinetic models as a function of Molarity of $\mathrm{HNO}_{3}$

\begin{tabular}{ccccccc}
\hline \multirow{2}{*}{ Variable } & $\begin{array}{c}\text { Diffusion through the liquid film, } \\
\alpha=\mathrm{k}_{\mathrm{l}} \mathrm{t}\end{array}$ & \multicolumn{2}{c}{$\begin{array}{c}\text { Surface chemical reaction, } \\
1-(1-\alpha)^{1 / 3}=\mathrm{k}_{\mathrm{r}} \mathrm{t}\end{array}$} & $\begin{array}{c}\text { Diffusion through the product layer, } \\
1-(2 / 3) \alpha-(1-\alpha)^{2 / 3}=\mathrm{k}_{\mathrm{d}} \mathrm{t}\end{array}$ \\
\hline Molarity & Equation & $\mathrm{R}^{2}$ & Equation & $\mathrm{R}^{2}$ & Equation & $\mathrm{R}^{2}$ \\
\hline $3 \mathrm{M}$ & $\mathrm{y}=0.3974 \mathrm{t}+0.0933$ & 0.9434 & $\mathrm{y}=0.217 \mathrm{t}+0.0144$ & 0.9865 & $\mathrm{y}=0.0702 \mathrm{t}-0.0119$ & 0.9473 \\
$4 \mathrm{M}$ & $\mathrm{y}=0.418 \mathrm{t}+0.1424$ & 0.8492 & $\mathrm{y}=0.237 \mathrm{t}+0.0449$ & 0.912 & $\mathrm{y}=0.08 \mathrm{t}+0.00004$ & 0.9358 \\
$5 \mathrm{M}$ & $\mathrm{y}=0.4282 \mathrm{t}+0.1541$ & 0.8278 & $\mathrm{y}=0.2506 \mathrm{t}+0.0517$ & 0.8861 & $\mathrm{y}=0.087 \mathrm{t}+0.0026$ & 0.9034 \\
$6 \mathrm{M}$ & $\mathrm{y}=0.6076 \mathrm{t}+0.0939$ & 0.9062 & $\mathrm{y}=0.3275 \mathrm{t}+0.037$ & 0.9561 & $\mathrm{y}=0.1254 \mathrm{t}-0.0064$ & 0.963 \\
\hline
\end{tabular}

Table 2. The correlation coefficient values $\left(\mathrm{R}^{2}\right)$ of three kinetic models as a function of temperature

\begin{tabular}{lcccccc}
\hline & $\begin{array}{c}\text { Diffusion through the liquid } \\
\text { film, } \alpha=\mathrm{kt}\end{array}$ & \multicolumn{2}{c}{$\begin{array}{c}\text { Surface chemical reaction, } \\
1-(1-\alpha)^{1 / 3}=\mathrm{k}_{\mathrm{r}} \mathrm{t}\end{array}$} & \multicolumn{2}{c}{$\begin{array}{c}\text { Diffusion through the product layer } \\
1-(2 / 3) \alpha-(1-\alpha)^{2 / 3}=\mathrm{k}_{\mathrm{d}} \mathrm{t}\end{array}$} \\
\hline Various & Equation & $\mathrm{R}^{2}$ & Equation & $\mathrm{R}^{2}$ & Equation & $\mathrm{R}^{2}$ \\
\hline $301 \mathrm{~K}$ & $\mathrm{y}=0.418 \mathrm{t}+0.1424$ & 0.8492 & $\mathrm{y}=0.237 \mathrm{t}+0.0449$ & 0.9120 & $\mathrm{y}=0.08 \mathrm{t}+0.00004$ & 0.9358 \\
$313 \mathrm{~K}$ & $\mathrm{y}=0.4744 \mathrm{t}+0.1649$ & 0.8219 & $\mathrm{y}=0.3266 \mathrm{t}+0.051$ & 0.8878 & $\mathrm{y}=0.125 \mathrm{t}+0.0015$ & 0.8874 \\
$323 \mathrm{~K}$ & $\mathrm{y}=0.499 \mathrm{t}+0.1726$ & 0.8312 & $\mathrm{y}=0.4387 \mathrm{t}+0.0213$ & 0.9638 & $\mathrm{y}=0.1703 \mathrm{t}-0.0095$ & 0.9453 \\
$333 \mathrm{~K}$ & $\mathrm{y}=0.5002 \mathrm{t}+0.1906$ & 0.8003 & $\mathrm{y}=0.4793 \mathrm{t}+0.0423$ & 0.9086 & $\mathrm{y}=0.1831 \mathrm{x}+0.0011$ & 0.8759 \\
\hline
\end{tabular}

While the surface chemical reaction model has a range of $\mathrm{R}^{2}$ from 0.8878 to 0.9638 , diffusion through the product layer model has a range of $\mathrm{R}^{2}$ from 0.8759 to 0.9453 . With the narrowest range of $\mathrm{R}^{2}$, this study predicts that the surface chemical reaction model is the control reaction of ZOC dissolution in $\mathrm{HNO}_{3}[14,19]$. The selection of the control mechanism for $\mathrm{ZOC}$ dissolution reactions in $\mathrm{HNO}_{3}$ turned out to be in accordance with white frit $\mathrm{Zr}$ with temperature variations [12].

From the regression equation of $\mathrm{Y}=\mathrm{a}+\mathrm{bX}$ (Table 1

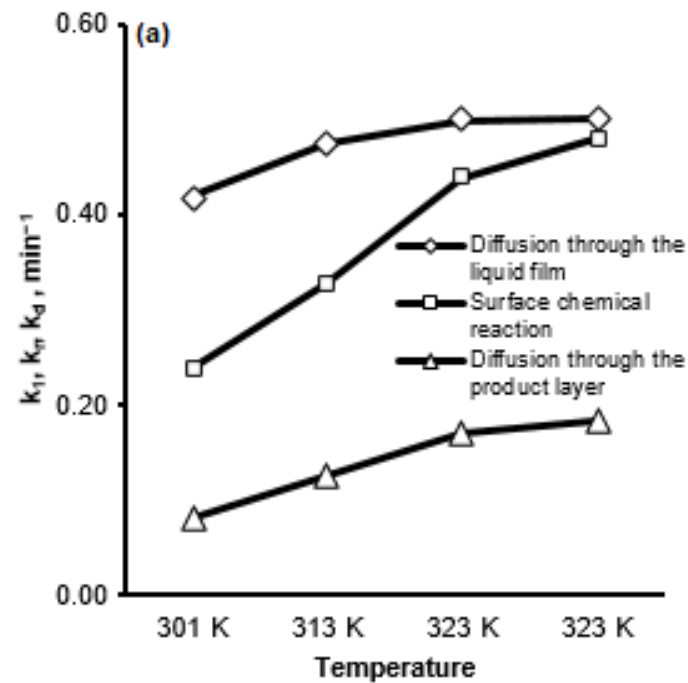

and 2), the value of the constant of $k_{1}, k_{r}$, and $k_{d}$ can be obtained from the slope [20]. Fig. 8(a) shows the relationship between rate constants $\mathrm{k}_{1}, \mathrm{k}_{\mathrm{r}}$ and $\mathrm{k}_{\mathrm{d}}$ versus molarity $\mathrm{HNO}_{3}$, while Fig. 8(b) shows the relationship between rate constants $k_{1}, k_{r}$ and $k_{d}$ versus temperature each in the three models of equations (2-4).

In Fig. 8(a) and 8(b), it can be shown that the greater the molarity of $\mathrm{HNO}_{3}$ and temperature, the rate constants values of $k, k_{r}$ and $k_{d}$ will tend to increase with three shrinking core models (2), (3) and (4). In order to

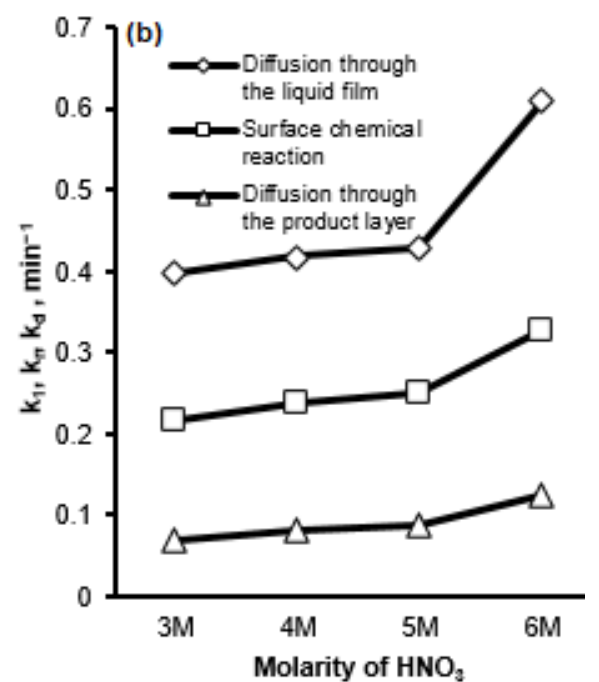

Fig 8. The plot of (a) temperature (T) versus $k_{1}, k_{r}$ and $k_{d}$, and (b) the plot of molarity of $H_{N O} O_{3}$ versus $k_{1}, k_{r}$, and $k_{d}$ on the three shrinking core models respectively 
Table 3. Value of rate constants of $k_{r}$ at various temperature

\begin{tabular}{cccc}
\hline $\mathrm{K}$ & $\mathrm{k}, 1 / \mathrm{min}$ & $1 / \mathrm{T}$ & $\ln \mathrm{k}$ \\
\hline 301 & 0.2370 & 0.0033 & -1.4397 \\
313 & 0.3266 & 0.0032 & -1.1190 \\
323 & 0.4387 & 0.0031 & -0.8239 \\
333 & 0.4793 & 0.0030 & -0.7354 \\
\hline
\end{tabular}

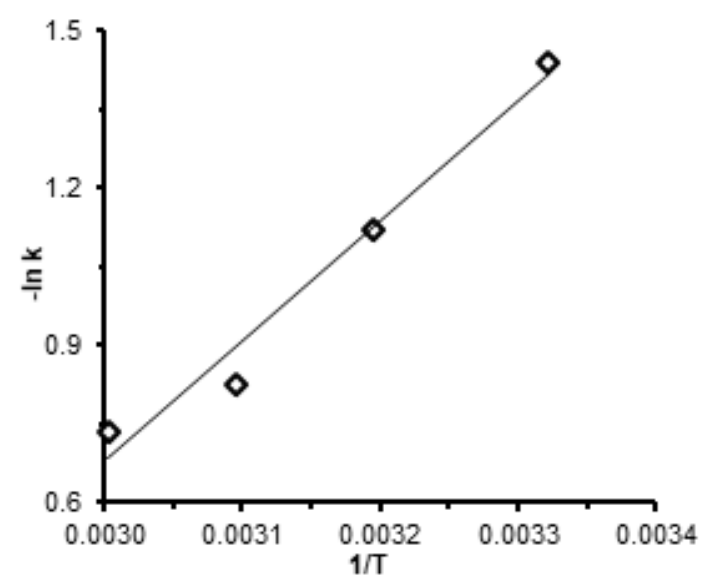

Fig 9. Correlation graph of $1 / \mathrm{T}(\mathrm{K})$ with - $\ln \mathrm{k}$

make the design of the chemical reactors, ZOC dissolution was inseparable from the selection of price rate constants from the results of experiments [14]. The price of rate constants values of k, kr, and kd in Fig. 8(b) cannot be used because it has been optimized in Fig. 3 . Thus, the selection of rate constants values of $k, k_{r}$, and $k_{d}$ in Fig. 8(b) can be ignored. Furthermore, in Fig. 8(a), it can be shown that the diffusion through the fluid film model has the highest rate of constants. Although this model has the highest rate of constants values, this model is not a reaction controller for dissolving $\mathrm{ZOC}$ in $\mathrm{HNO}_{3}$. Based on the data in Table 2, it turns out that a controller of the ZOC dissolution reaction is a surface chemical reaction model (no. 2). In the case of designing the $\mathrm{ZOC}$ dissolution reactor in $\mathrm{HNO}_{3}$, the rate of constants values selection was in accordance with Levenspiel [14]. Considering the selection of high rate constants values will result in the reactor volume being too large and expensive, while the low rate constants values lead to the imperfect reaction and the length of contact time [14].

Furthermore, after obtaining the reaction rate constant $(\mathrm{k})$ data at each temperature change (Table 3), the data can be expanded by referring to the Arrhenius equation, $\ln \mathrm{k}=\ln \mathrm{A}-\mathrm{Ea} /(\mathrm{R} . \mathrm{T})$. The calculation results were expressed in a straight line graph between $\ln \mathrm{k}$ as ordinate and 1/T as the observable abscissa in Fig. 9.

From Fig. 9, the correlation between 1/T and $\ln \mathrm{k}$, the equation of $\ln \mathrm{ks}=-2297.6 / \mathrm{T}+6.2172$ was obtained. The linearity of 0.9718 was sufficient to calculate the frequency factor and the activation energy based on slope and intercept values. The activation energy is defined as the energy that must be exceeded for a chemical reaction to occur. Meanwhile, the frequency factor (A) depends on the weight and molecular structure, frequency, and position of collisions between molecules. The value of the frequency factor (A) can be determined from the intercept, and the activation energy (E) is the slope value multiplied by $\mathrm{R}$ (gas constant $8.314 \mathrm{~J} /$ mole.K).

\section{- CONCLUSION}

Optimization and kinetics reactions data of ZOC dissolution in $\mathrm{HNO}_{3}$ to obtain reactor design have been conducted. With ZOC $6 \mathrm{~g}$ of feed and 2 min contact time, $6 \mathrm{M} \mathrm{HNO}_{3}$ concentration, stirring speed of $75 \mathrm{rpm}$, and the optimum temperature of $60^{\circ} \mathrm{C}$, the maximum conversion value obtained was 0.96 . The results of the kinetic study predict that the control of the ZOC dissolution reaction in $\mathrm{HNO}_{3}$ is in accordance with the surface chemical reaction model. The correlation between temperature $(\mathrm{T})$ and reaction rate constant $(\mathrm{k})$ obtained the frequency factor (A) of 501.29 and activation energy (E) of $19.09 \mathrm{~kJ} / \mathrm{mole}$.

\section{- ACKNOWLEDGMENTS}

With the completion of writing this paper, the author would like to thank Dr. Susilo Widodo, Suyanti S.Si., and Ir. Herry Poernomo, MT each as a supervisor and Chair of the PSTA, head of the BTP and chair of the TPZ working group who helped a lot in terms of funding through DIPA 2017 with number SP DIPA/080.01.1.017 290/2017. The authors are also very grateful to Mrs. Suprihati and Mr. Sri Sukmojaya who have helped a lot in the laboratory.

\section{- REFERENCES}

[1] Setyawan, W., 2015, Pengembangan teknologi pengolahan pasir zirkon lokal Indonesia menjadi 
produk zirkonium grade industri dan nuklir untuk mendukung MP3EI, Laporan akhir Program Insinas Riset SiNas, PSTA-Batan, Yogyakarta.

[2] Wang, L.Y., and Lee, M.S., 2014, Separation of zirconium and hafnium from nitric acid solutions with LIX 63, PC 88A and their mixture by solvent extraction, Hydrometallurgy, 150, 153-160.

[3] Biswas, R.K., Habib, M.A., and Islam, M.R., 2010, A novel method for processing of Bangladeshi zircon: Part II: Leaching of zircon-caustic fused mass by hydro chloric acid, Hydrometallurgy, 103 (1-4), 130-135.

[4] Liu, J., Song, J., Qi, T., Zhang, C., and Qu., J., 2016, Controlling the formation of $\mathrm{Na}_{2} \mathrm{ZrSiO}_{5}$ in alkali fusion process for zirconium oxychloride production, Adv. Powder Technol., 27 (1), 1-8.

[5] Biyantoro, D., Isyuniarto, and Masrukan, 2016, Pemisahan Zr-Hf secara sinambung menggunakan mixer settler, Urania, 22 (3), 155-166.

[6] Cox, R.P., and Bayer, G.H., 1955, Separation of hafnium from zirconium using tributyl phosphate, Ames Laboratory ISC Technical Reports, 109, Iowa State University.

[7] Pandey, G., Mukhopadhyay, S., Renjith, A.U., Joshi, J.M., and Shenoy, K.T., 2016, Recovery of Hf and Zr from slurry waste of zirconium purification plant using solvent extraction, Hydrometallurgy, 163, 61-68.

[8] Banda, R., and Lee, M.S., 2015, Solvent extraction for the separation of $\mathrm{Zr}$ and $\mathrm{Hf}$ from aqueous solutions, Sep. Purif. Rev., 44 (3), 199-215.

[9] Aliakbari, M., Saberyan, K., Noaparast, M., Abdollahi, H., and Akcil, A., 2014, Separation of hafnium and zirconium using TBP modified ferromagnetic nanoparticles: Effects of acid and metals concentrations, Hydrometallurgy, 146, 72-75.

[10] Biswas, R.K., Habib, M.A., and Hayat, M.A., 2004, Kinetics of solvent extraction of zirconium (IV) from chloride medium by D2EPHA in kerosene using the Lewis cell technique: A comparison with single drop technique, Pak. J. Sci. Ind. Res., 47 (5), 325-331.

[11] Murali, R., Augustine, E., Ganesh, S., Desigan, N., Pandey, N.K., Mallika, C., Mudali, U.K., and Joshi, J.B., 2016, Kinetics of extraction of zirconium with
TBP, The $7^{\text {th }}$ DAE-BRNS Biennial Symposium on Emerging Trends in Separation Science and Technology, SESTEC-2016, Indian Institute of Technology Guwahati, Assam, India, 17-20 May 2016.

[12] Barba, A., Jarque, J.C., Orduña, M., and Gazulla, M.F., 2015, Kinetic model of the dissolution process of a zirconium white frit. Influence of the temperature, J. Eur. Ceram. Soc., 35 (2), 751-764.

[13] Pandey, N.K., Murali, R., Augustine, E., Ganesh, S., and Joshi, J.B., 2017, Kinetics of interphase transfer of zirconium between nitric acid and tributyl phosphate solutions, J. Radioanal. Nucl. Chem., 314 (3), 1991-2001.

[14] Levenspiel, O., 1999, Chemical Reaction Engineering, $3^{\text {rd }}$ Ed., John Wiley \& Sons, New York.

[15] Gharabaghi, M., Irannajad, M., and Azadmehr, A.R., 2013, Leaching kinetics of nickel extraction from hazardous waste by sulphuric acid and optimization dissolution conditions, Chem. Eng. Res. Des., 91 (2), 325-331.

[16] Safari, V., Arzpeyma, G., Rashchi, F., and Mostoufi, N., 2009, A shrinking particle-shrinking core model for leaching of a zinc ore containing silica, Int. J. Miner. Process., 93 (1), 79-83.

[17] Pandey, N.K., Augustine, E., Murali, R., Desigan, N., Mudali, U.K., and Joshi J.B., 2016, Kinetics of extraction of nitric acid into binary mixture of trin-butyl phosphate and normal paraffin hydrocarbon, Chem. Eng. Res. Des., 111, 492-503.

[18] Salmi, T., Grénman, H., Wärnå, J., and Murzin, D.Y., 2013, New modelling approach to liquid-solid reaction kinetics: From ideal particles to real particles, Chem. Eng. Res. Des., 91 (10), 1876-1889.

[19] Ayanda, O.S., Adekola, F.A., and Baba, A.A., 2011, Comparative study of the kinetics of dissolution of laterite in some acidic media, JMMCE, 10 (15), 1457-1472.

[20] Miller, J.N., and Miller, J.C., 2010, Statistics and Chemometrics for Analytical Chemistry, $6^{\text {th }}$ Ed., Pearson Education Limited, Harlow, UK. 